\title{
Bacillus purgationiresistans sp. nov., isolated from a drinking-water treatment plant
}

Correspondence
Célia M. Manaia
cmmanaia@esb.ucp.pt

\author{
Ivone Vaz-Moreira, ${ }^{1,2}$ Vânia Figueira, ${ }^{1}$ Ana R. Lopes, ${ }^{2}$ \\ Alexandre Lobo-da-Cunha, ${ }^{3}$ Cathrin Spröer, ${ }^{4}$ Peter Schumann, ${ }^{4}$ \\ Olga C. Nunes ${ }^{2}$ and Célia M. Manaia ${ }^{1}$
}
${ }^{1}$ CBOF - Escola Superior de Biotecnologia, Universidade Católica Portuguesa, 4200-072 Porto, Portugal
${ }^{2}$ LEPAE - Departamento de Engenharia Química, Faculdade de Engenharia, Universidade do Porto, 4200-465 Porto, Portugal
${ }^{3}$ Laboratory of Cell Biology, Institute of Biomedical Sciences Abel Salazar (ICBAS), University of Porto, 4099-003 Porto, Portugal
${ }^{4} \mathrm{DSMZ}$ - Deutsche Sammlung von Mikroorganismen und Zellkulturen GmbH, Inhoffenstraße 7B, D-38124 Braunschweig, Germany

\begin{abstract}
A Gram-positive, aerobic, non-motile, endospore-forming rod, designated DS22 ${ }^{\top}$, was isolated from a drinking-water treatment plant. Cells were catalase- and oxidase-positive. Growth occurred at $15-37{ }^{\circ} \mathrm{C}$, at $\mathrm{pH} \mathrm{7-10}$ and with $<8 \%(\mathrm{w} / \mathrm{v}) \mathrm{NaCl}$ (optimum growth: $30{ }^{\circ} \mathrm{C}, \mathrm{pH} 7-8$ and $1-3 \% \mathrm{NaCl}$ ). The major respiratory quinone was menaquinone 7 , the $\mathrm{G}+\mathrm{C}$ content of the genomic DNA was $36.5 \mathrm{~mol} \%$ and the cell wall contained meso-diaminopimelic acid. On the basis of $16 \mathrm{~S}$ rRNA gene sequence analysis, strain $\mathrm{DS} 22^{\top}$ was a member of the genus Bacillus. Its closest phylogenetic neighbours were Bacillus horneckiae NRRL B-59162 ${ }^{\top}$ (98.5\% $16 \mathrm{~S}$ rRNA gene sequence similarity), Bacillus oceanisediminis $\mathrm{H}^{\top}{ }^{\top}(97.9 \%)$, Bacillus infantis SMC $4352-1^{\top}(97.4 \%)$, Bacillus firmus IAM $12464^{\top}(96.8 \%)$ and Bacillus muralis LMG $20238^{\top}$ (96.8\%). DNA-DNA hybridization, and biochemical and physiological characterization allowed the differentiation of strain $\mathrm{DS} 22^{\top}$ from its closest phylogenetic neighbours. The data supports the proposal of a novel species, Bacillus purgationiresistans sp. nov.; the type strain is DS22 ${ }^{\top}$ $\left(=\right.$ DSM $23494^{\top}=$ NRRL B $-59432^{\top}=$ LMG $\left.25783^{\top}\right)$.
\end{abstract}

Gram-positive endospore-forming bacteria of the genus Bacillus are widespread in nature and can be found in a large variety of environments, such as terrestrial and aquatic habitats, clinical samples and even spacecraftassembly facilities. Such ubiquity is also reflected in the phenotypic and phylogenetic diversity of this genus, which currently includes more than 150 species (Logan et al., 2009).

In many world regions, drinking-water treatment involves the disinfection processes of ozonation and chlorination. Such treatments are known to impose dramatic changes in the water's bacterial population, markedly by a shift to Gram-positive bacteria, namely endospore formers of the genus Bacillus (Norton \& LeChevallier, 2000). A single strain, designated $\mathrm{DS} 22^{\mathrm{T}}$, was isolated from a drinkingwater treatment plant located in northern Portugal. In this

\footnotetext{
Abbreviation: FAMEs, fatty acid methyl esters.
}

The GenBank/EMBL/DDBJ accession number for the 16S rRNA gene sequence of strain DS22 ${ }^{\top}$ is FR666703. plant, the water is collected from a river basin and treated by initial filtration, ozonation and treatment with activated carbon followed by a final disinfection with chlorine. According to our data (unpublished), this treatment reduces the number of total cells by $99 \%$ and the number of cultivable bacterial counts by about $98 \%$. After membrane filtration of 11 water from the final reservoir, strain $\mathrm{DS} 22^{\mathrm{T}}$ was isolated on mannitol salt agar (MSA; Pronadisa). The isolate was purified by subcultivation on plate count agar (PCA; Pronadisa), which contains $\left(1^{-1}\right): 5$ g tryptone, 2.5 g yeast extract, $1 \mathrm{~g}$ glucose, $15 \mathrm{~g}$ agar. Cultures were incubated at $30{ }^{\circ} \mathrm{C}$. Strain $\mathrm{DS} 22^{\mathrm{T}}$ was preserved at $-80{ }^{\circ} \mathrm{C}$ in nutrient broth with $15 \%(\mathrm{v} / \mathrm{v})$ glycerol.

Colony and cell morphology, Gram-staining, cytochrome $c$ oxidase and catalase tests, endospore production, motility and casein hydrolysis were analysed according to the methodologies of Murray et al. (1994) and Smibert \& Krieg (1994). Additional phenotypic characterization was based on methods described previously (Vaz-Moreira et al., 2007a, 2010). Conditions for growth were tested at 
6-40 ${ }^{\circ} \mathrm{C}$, with $0.1-10.0 \%(\mathrm{w} / \mathrm{v}) \mathrm{NaCl}$ and at $\mathrm{pH} 5.0-10.5$. Biochemical and nutritional tests were performed using the API 20NE, API ZYM and API 50CH systems inoculated with API $50 \mathrm{CHB} / \mathrm{E}$ medium (bioMérieux), according to the manufacturer's instructions. Additionally, the assimilation of L-alanine, L-histidine, lactic acid, L-proline, propionic acid and L-serine was tested in mineral medium $\mathrm{B}$ supplemented with $4 \mathrm{mM}\left(\mathrm{NH}_{4}\right)_{2} \mathrm{SO}_{4}$ and $40 \mu \mathrm{g}$ vitamins and nitrogenated bases $1^{-1}$ and $5 \mathrm{mg}$ amino acids $\mathrm{l}^{-1}$ (Vaz-Moreira et al., 2007b). The Voges-Proskauer test was assayed in methyl red and Voges-Proskauer media (Oxoid) at $30{ }^{\circ} \mathrm{C}$ for $48 \mathrm{~h}$. Hydrolysis of Tween 80 and starch was tested as described by Tiago et al. (2004). The ability to grow on MSA and Bacillus cereus agar (Bio-Rad) at $30^{\circ} \mathrm{C}$ was tested after 4 days of incubation. Lecithinase activity was observed on B. cereus agar supplemented with egg yolk (Merck) by the formation of a translucent halo. Production of gas from glucose was tested in glucose broth (Pronadisa). Phenotypic tests, for which results may vary between different laboratories, were assayed in parallel with the reference strains Bacillus oceanisediminis $\mathrm{H} 2^{\mathrm{T}}$, Bacillus horneckiae NRRL B-59162 ${ }^{\mathrm{T}}$, Bacillus muralis DSM $16288^{\mathrm{T}}$, Bacillus firmus DSM $12^{\mathrm{T}}$ and Bacillus infantis DSM $19098^{\mathrm{T}}$.

Endospores were observed by transmission electron microscopy. Bacteria were fixed for $4 \mathrm{~h}$ at $4{ }^{\circ} \mathrm{C}$ in $2.5 \%$ glutaraldehyde and $4 \%$ formaldehyde (obtained from hydrolysis of para-formaldehyde) diluted with $0.1 \mathrm{M}$ cacodylate buffer ( $\mathrm{pH}$ 7.4). After washing in the same buffer, bacteria were post-fixed overnight in $2 \% \mathrm{OsO}_{4}$ buffered with cacodylate, washed in buffer, treated with $1 \%$ uranyl acetate for $1 \mathrm{~h}$, dehydrated in increasing concentrations of ethanol and embedded in Epon. Ultrathin sections were stained with uranyl acetate and lead citrate and observed in a JEOL 100CXII transmission electron microscope $(60 \mathrm{kV})$. The $\mathrm{G}+\mathrm{C}$ content of the genomic DNA and the respiratory quinones were analysed as described previously (Vaz-Moreira et al., 2007a) using the methods of Mesbah et al. (1989) and Tindall (1989), respectively. The polar lipid composition was determined as described previously (Manaia et al., 2004). Fatty acid methyl esters (FAMEs) were analysed using cells prepared for $24 \mathrm{~h}$ on tryptic casein soy agar (TSA; Pronadisa) at $28{ }^{\circ} \mathrm{C}$. All six strains (the isolate and the five reference strains) grew as expected and provided sufficient cells of comparable physiological age from the third streak on TSA. Cell harvesting and FAME preparation were performed as described by Kuykendall et al. (1988). The separation, identification and quantification of the individual FAMEs were done using the Sherlock Microbial Identification System version 4.6 (MIDI). FAMEs were extracted and analysed twice. Diaminopimelic acid isomers in whole-cell hydrolysates $\left(4 \mathrm{M} \mathrm{HCl}, 100{ }^{\circ} \mathrm{C}, 16 \mathrm{~h}\right)$ were analysed by TLC on cellulose plates using described solvent systems (Rhuland et al., 1955; Schleifer \& Kandler, 1972).

The nucleotide sequence of the 16S rRNA gene was determined after PCR amplification of total DNA extracts as described elsewhere (Ferreira da Silva et al., 2007). The $16 \mathrm{~S}$ rRNA gene sequence was compared with others available in the public databases using the FASTA package from EMBL-EBI (http://www.ebi.ac.uk). Phylogenetic analysis was conducted using MEGA version 4.0.2 (Tamura et al., 2007). Sequence relatedness was estimated using the model of Jukes \& Cantor (1969) and dendrograms were created using the neighbour-joining method. Tree stability was assessed by also constructing trees with the maximumparsimony and maximum-likelihood methods. Non-homologous and ambiguous nucleotide positions were excluded from the calculations and a total of $1149 \mathrm{nt}$ positions were included in the analysis. For spectroscopic DNA-DNA hybridization, cells were disrupted using a French pressure
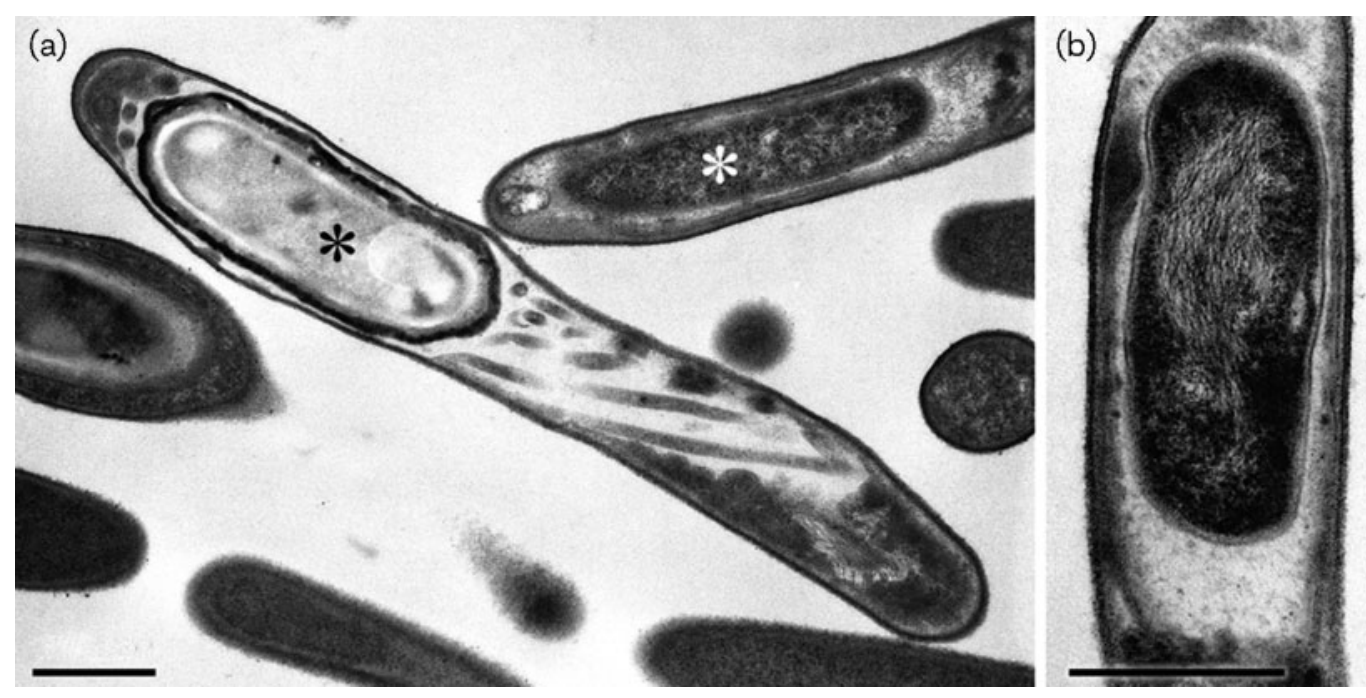

Fig. 1. Transmission electron micrographs of cells of strain $D S 22^{\top}$. (a) Cells after growth for 2 days at $30{ }^{\circ} \mathrm{C}$ on nutrient agar, showing cell morphology and endospore positions (asterisks). (b) Detail of an endospore. Bars, $0.5 \mu \mathrm{m}$. 
cell (Thermo Spectronic) and DNA in the crude lysate was purified by chromatography on hydroxyapatite as described by Cashion et al. (1977). DNA-DNA hybridization was carried out as described by De Ley et al. (1970) under consideration of the modifications described by Huß et al. (1983) using a model Cary 100 Bio UV/VIS-spectrophotometer equipped with a Peltier-thermostatted $6 \times 6$ multicell changer and a temperature controller with an in situ temperature probe (Varian).
On TSA after $48 \mathrm{~h}$ at $30{ }^{\circ} \mathrm{C}$, strain DS $22^{\mathrm{T}}$ formed white, slightly convex colonies with irregular margins (approximately $2 \mathrm{~mm}$ in diameter). Growth on other media such as PCA, R2A agar (Difco) and B. cereus agar was slightly slower. Even though strain DS $22^{\mathrm{T}}$ was isolated on MSA, growth was not observed on this medium. This could have been because of different culture conditions, as this study isolated the strain with the membrane-filtration method, which avoids direct contact between cells and the medium,

Table 1. Distinctive characteristics of strain $\mathrm{DS} 22^{\top}$ and its closest phylogenetic neighbours

Strains: 1 , Bacillus purgationiresistans sp. nov. DS22 $2^{\mathrm{T}} ; 2$, B. horneckiae NRRL B- $59162^{\mathrm{T}} ; 3$, B. oceanisediminis $\mathrm{H}_{2}^{\mathrm{T}} ; 4$, B. muralis DSM $16288^{\mathrm{T}} ; 5, B$. firmus DSM $12^{\mathrm{T}} ; 6$, B. infantis DSM $19098^{\mathrm{T}}$. Data are from this study unless otherwise indicated. +, Positive; w, weakly positive; -, negative; ND, no data available.

\begin{tabular}{|c|c|c|c|c|c|c|}
\hline Characteristic & 1 & 2 & 3 & 4 & 5 & 6 \\
\hline Colony pigmentation & White & White & White & Pink & White & Pink \\
\hline \multicolumn{7}{|l|}{ Growth on/at: } \\
\hline MSA & - & + & + & - & - & + \\
\hline $40{ }^{\circ} \mathrm{C}$ & - & + & + & + & + & + \\
\hline $9 \% \mathrm{NaCl}$ & - & + & + & - & - & + \\
\hline Nitrate reduction & - & + & + & $-^{*}$ & + & - \\
\hline Cytochrome $c$ oxidase & + & - & + & + & - & - \\
\hline \multicolumn{7}{|l|}{ Hydrolysis of: } \\
\hline Starch & - & - & + & $-*$ & $-*$ & + \\
\hline Aesculin & - & - & - & + & - & $\mathrm{w}$ \\
\hline \multicolumn{7}{|l|}{ Assimilation of: } \\
\hline D-Glucose & - & - & + & + & + & + \\
\hline L-Arabinose & - & - & - & + & - & - \\
\hline D-Mannose & - & - & - & + & - & - \\
\hline D-Mannitol & - & - & - & + & + & + \\
\hline$N$-Acetylglucosamine & - & - & + & + & + & w \\
\hline Maltose & - & + & + & + & + & + \\
\hline Potassium gluconate & - & + & + & + & - & + \\
\hline Adipate & - & + & - & - & - & - \\
\hline Malate & - & + & + & - & $\mathrm{w}$ & + \\
\hline Citrate & - & + & $t^{*}$ & + & - & - \\
\hline L-Alanine & - & + & + & + & - & - \\
\hline L-Histidine & - & + & + & + & - & - \\
\hline Lactic acid & - & - & $-*$ & + & + & + \\
\hline L-Proline & - & + & - & + & + & - \\
\hline Propionic acid & - & - & - & + & - & - \\
\hline L-Serine & - & + & + & + & + & - \\
\hline \multicolumn{7}{|l|}{ Enzymes } \\
\hline Alkaline phosphatase & - & + & + & + & - & - \\
\hline Leucine arylamidase & + & + & + & + & + & - \\
\hline Trypsin & - & - & - & - & - & + \\
\hline$\alpha$-Chymotrypsin & + & + & + & + & - & $\mathrm{w}$ \\
\hline Acid phosphatase & - & + & - & - & - & - \\
\hline$\beta$-Galactosidase & - & - & $-*$ & + & - & + \\
\hline$\alpha$-Glucosidase & - & - & + & + & + & + \\
\hline DNA G $+\mathrm{C}$ content $(\mathrm{mol} \%) \dagger \ddagger$ & 36.5 & $35.6^{a}$ & $44.8^{b}$ & $\mathrm{ND}$ & $46.1-47.4^{d}$ & $40.8^{e}$ \\
\hline Isolation sourceł & Treated water & Clean room $^{a}$ & Sediment ${ }^{b}$ & Mural painting $^{c}$ & Soil $^{d}$ & Sepsis ${ }^{e}$ \\
\hline
\end{tabular}

${ }^{\star}$ Differs from the original description.

$\dagger$ DNA G + C values for columns 1 and 5 were determined by HPLC; values for columns 2, 3 and 6 were determined by thermal denaturation. \$Data were taken from: $a$, Vaishampayan et al. (2010); b, Zhang et al. (2010); c, Heyrman et al. (2005); d, Sneath (1986); e, Ko et al. (2006). 
or because the $\mathrm{NaCl}$ concentration in MSA (7.5\%) is close to the upper limit for growth of strain DS $22^{\mathrm{T}}$. Strain DS22 ${ }^{\mathrm{T}}$ formed subterminal endospores in a non-swollen sporangium (Fig. 1).

The G $+C$ content of the genomic DNA of strain DS22 ${ }^{\mathrm{T}}$ was determined to be $36.5 \pm 0.12 \mathrm{~mol} \%$ (Table 1). Strain DS22 ${ }^{\mathrm{T}}$ had the respiratory quinone menaquinone 7 (MK7) and the cell wall contained meso-diaminopimelic acid. The major cellular fatty acids were iso- $\mathrm{C}_{15: 0}, \mathrm{C}_{16: 1} \omega 7 c$ alcohol, anteiso- $\mathrm{C}_{15: 0}$ and iso- $\mathrm{C}_{14: 0}$ (Table 2). The polar lipid analysis showed the predominance of phosphatidylethanolamine, phosphatidylglycerol and diphosphatidylglycerol (Fig. 2), which are characteristic of the genus Bacillus (Kämpfer et al., 2006; Vaishampayan et al., 2010; Zhang et al., 2010). The unidentified phospholipids found in strain $\mathrm{DS} 22^{\mathrm{T}}$ are also present in $B$. horneckiae NRRL B-59162 ${ }^{\mathrm{T}}$ (Vaishampayan et al., 2010) and included three phospholipids and two aminophospholipids. One of the aminophospholipids has also been found in B. subtilis DSM $10^{\mathrm{T}}$ (Kämpfer et al., 2006). However, the glycolipid $\beta$ gentiobiosyldiacylglycerol, which is present in B. subtilis
DSM $10^{\mathrm{T}}$ (Kämpfer et al., 2006), was not detected in strain DS22 $2^{\mathrm{T}}$.

The chemotaxonomic characterization of strain $\mathrm{DS} 22^{\mathrm{T}}$ was confirmed by the results of the 16S rRNA gene sequence analysis. In the neighbour-joining tree, strain $\mathrm{DS} 22^{\mathrm{T}}$ was placed in a cluster within the genus Bacillus (Fig. 3). Strain $\mathrm{DS} 22^{\mathrm{T}}$ was most closely related to B. horneckiae NRRL B$59162^{\mathrm{T}}$ (98.5\% $16 \mathrm{~S}$ rRNA gene sequence similarity), $B$. oceanisediminis $\mathrm{H}^{\mathrm{T}}(97.9 \%)$, B. infantis SMC 4352-1 ${ }^{\mathrm{T}}$ $(97.4 \%)$, B. firmus IAM $12464^{\mathrm{T}}(96.8 \%)$ and B. muralis LMG $20238^{\mathrm{T}}(96.8 \%)$.

Strain DS22 ${ }^{\mathrm{T}}$ was compared with the reference strains with respect to phenotypic properties (Table 1) and cellular fatty acid composition (Table 2), which allowed the observation of distinctive features. Strain DS22 ${ }^{\mathrm{T}}$ could be distinguished phenotypically from all of the reference strains by its inability to grow at $40{ }^{\circ} \mathrm{C}$ and assimilate any of the tested carbon sources, from B. muralis DSM $16288^{\mathrm{T}}$ and $B$. infantis DSM $19098^{\mathrm{T}}$ by colony colour, from B. horneckiae NRRL B-59162 $2^{\mathrm{T}}, B$. oceanisediminis $\mathrm{H} 2^{\mathrm{T}}$ and B. firmus DSM $12^{\mathrm{T}}$ by its inability to reduce nitrate, and from $B$.

Table 2. Cellular fatty acid compositions of strain $\mathrm{DS} 22^{\top}$ and its closest phylogenetic neighbours

Strains 1, Bacillus purgationiresistans sp. nov. DS22 ${ }^{\mathrm{T}} ; 2$, B. horneckiae NRRL B-59162 ${ }^{\mathrm{T}} ; 3$, B. oceanisediminis $\mathrm{H}_{2}{ }^{\mathrm{T}}$; 4, B. muralis DSM $16288^{\mathrm{T}} ; 5$, B. firmus DSM $12^{\mathrm{T}} ; 6$, B. infantis DSM $19098^{\mathrm{T}}$. All data were taken from this study. Cells were cultivated on TSA at $28{ }^{\circ} \mathrm{C}$ for 24 h. - , Not detected.

\begin{tabular}{|c|c|c|c|c|c|c|}
\hline Fatty acid (\%) & 1 & 2 & 3 & 4 & 5 & 6 \\
\hline \multicolumn{7}{|l|}{ Saturated straight-chain } \\
\hline $\mathrm{C}_{14: 0}$ & 0.9 & 0.7 & 6.4 & 3.9 & 13.4 & 1.7 \\
\hline $\mathrm{C}_{15: 0}$ & - & - & - & - & - & - \\
\hline $\mathrm{C}_{16: 0}$ & 0.5 & 0.8 & 13.5 & 4.5 & 15.7 & 0.9 \\
\hline $\mathrm{C}_{16: 0} \mathrm{~N}$ alcohol & - & - & - & - & 0.3 & - \\
\hline \multicolumn{7}{|c|}{ Unsaturated straight-chain } \\
\hline $\mathrm{C}_{16: 1} \omega 5 c$ & - & - & 1.4 & - & 3.7 & - \\
\hline $\mathrm{C}_{16: 1} \omega 11 c$ & 2.5 & 2.1 & 13.1 & 9.4 & 14.6 & 1.5 \\
\hline $\mathrm{C}_{16: 1} \omega 7 c$ alcohol & 15.2 & 9.8 & 3.2 & 1.9 & 1.2 & 1.5 \\
\hline Summed feature $3^{\star}$ & - & - & 1.4 & - & 1.2 & - \\
\hline \multicolumn{7}{|c|}{ Saturated branched-chain } \\
\hline iso- $\mathrm{C}_{13: 0}$ & 0.2 & - & - & 0.3 & - & 0.2 \\
\hline iso- $\mathrm{C}_{14: 0}$ & 9.2 & 4.1 & 3.9 & 3.8 & 2.3 & 1.3 \\
\hline iso- $\mathrm{C}_{15: 0}$ & 41.9 & 51.1 & 27.7 & 27.7 & 23.9 & 49.2 \\
\hline iso- $\mathrm{C}_{16: 0}$ & 6.7 & 5.9 & 4.1 & 1.1 & 1.7 & 1.3 \\
\hline iso- $\mathrm{C}_{17: 0}$ & 1.1 & 3.2 & 1.6 & 1.2 & 0.9 & 1.4 \\
\hline anteiso- $\mathrm{C}_{13: 0}$ & - & - & - & 0.3 & - & 0.1 \\
\hline anteiso- $\mathrm{C}_{15: 0}$ & 14.2 & 13.5 & 15.8 & 42.1 & 16.5 & 29.9 \\
\hline anteiso- $\mathrm{C}_{17: 0}$ & 2.3 & 3.3 & 3.4 & 1.0 & 2.5 & 5.4 \\
\hline \multicolumn{7}{|c|}{ Unsaturated branched-chain } \\
\hline iso- $\mathrm{C}_{15: 1} \omega 9 c$ & - & - & - & 0.5 & - & 0.5 \\
\hline iso- $\mathrm{C}_{17: 1} \omega 10 c$ & 1.8 & 2.7 & 0.8 & 1.5 & 0.4 & 1.3 \\
\hline Summed feature $4^{*}$ & 3.5 & 2.9 & 2.0 & 0.9 & 1.5 & 3.7 \\
\hline
\end{tabular}

*Summed features represent two or three fatty acids that cannot be separated by the Microbial Identification System. Summed feature 3 consisted of $\mathrm{C}_{16: 1} \omega 7 c$ and/or $\mathrm{C}_{16: 1} \omega 6 c$. Summed feature 4 consisted of iso- $\mathrm{C}_{17: 1}$ and/ or anteiso- $\mathrm{C}_{17: 1}$. 


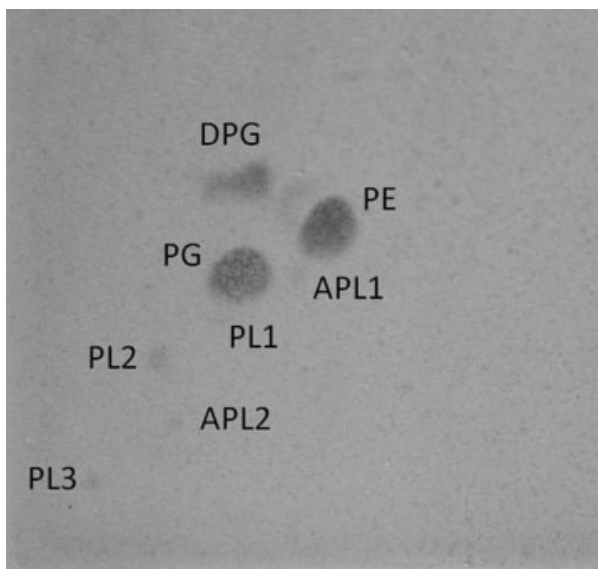

Fig. 2. Polar lipid profile of strain $D S 22^{\top}$ after separation by twodimensional TLC, spraying with $50 \%(\mathrm{v} / \mathrm{v})$ aqueous sulfuric acid and charring at $160{ }^{\circ} \mathrm{C}$ for 25 min. APL, Unknown aminophospholipid; DPG, diphosphatidylglycerol; PE, phosphatidylethanolamine; PG, phosphatidylglycerol; PL, unknown phospholipid. horneckiae NRRL B-59162 ${ }^{\mathrm{T}}$ by its inability to produce acid from API $50 \mathrm{CH}$ carbon sources. Strain DS22 ${ }^{\mathrm{T}}$ could also be distinguished from the reference strains on the basis of differences in the fatty acid composition, mainly because of the proportions of $\mathrm{C}_{16: 1} \omega 7 \mathrm{c}$ alcohol, iso- $\mathrm{C}_{14: 0}$ and iso$\mathrm{C}_{15: 0}$. The phenotypic and fatty acid data suggested that strain DS22 $2^{\mathrm{T}}$ represented a distinct novel species.

Low DNA-DNA relatedness was observed between strain DS22 ${ }^{\mathrm{T}}$ and its closest neighbours: 13.6 and $7.6 \%$ with $B$. oceanisediminis $\mathrm{H} 2{ }^{\mathrm{T}}, 32.3$ and $30.0 \%$ with $B$. horneckiae NRRL B-59162 ${ }^{\mathrm{T}}, 17.5$ and $12.9 \%$ with B. muralis DSM $16288^{\mathrm{T}}, 13.8$ and $13.7 \%$ with B. infantis DSM $19098^{\mathrm{T}}$, and 16.6 and $8.1 \%$ with $B$. firmus DSM $12^{\mathrm{T}}$. These values were clearly below the threshold of $70 \%$ DNA-DNA relatedness recommended for the definition of bacterial species (Wayne et al., 1987).

On the basis of the differentiation of strain DS22 ${ }^{\mathrm{T}}$ from its closest phylogenetic neighbours by $16 \mathrm{~S}$ rRNA gene sequence analysis, DNA-DNA relatedness, cellular fatty acids and physiological characters, strain DS22 ${ }^{\mathrm{T}}$ is proposed to represent a novel species, Bacillus purgationiresistans sp. nov.

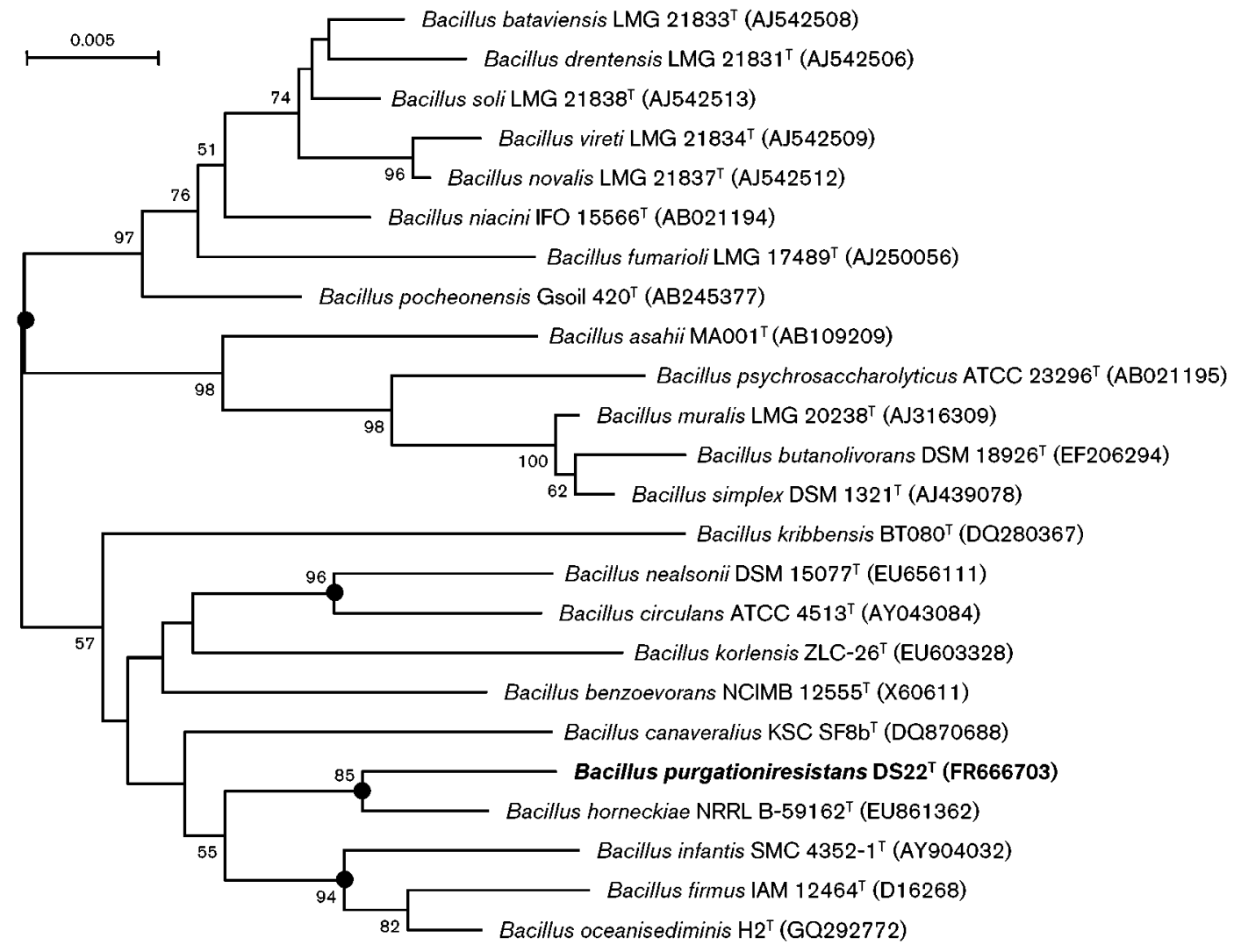

Fig. 3. Neighbour-joining phylogenetic tree derived from $16 \mathrm{~S}$ rRNA gene sequences, showing the relationships of strain DS22 ${ }^{\top}$ with members of the genus Bacillus. Bootstrap values $(\geqslant 50 \%)$ based on 1000 resamplings are shown at branch nodes. Filled circles indicate that the corresponding nodes were recovered in trees generated with the maximum-parsimony and maximumlikelihood methods. Bar, 1 substitution per 200 nt. 


\section{Description of Bacillus purgationiresistans sp. nov.}

Bacillus purgationiresistans (pur.ga.ti.o.ni.re.sis'tans. L. n. purgatio - onis a cleansing, purification; L. part. adj. resistens resisting; N.L. part. adj. purgationiresistans resisting cleansing, purification).

Colonies are white and slightly convex ( $2 \mathrm{~mm}$ diameter) with irregular edges on TSA after $48 \mathrm{~h}$ at $30{ }^{\circ} \mathrm{C}$. Forms pink colonies on B. cereus agar. Rods $(3.5 \mu \mathrm{m}$ long and $0.5 \mu \mathrm{m}$ wide in very young cultures) are non-motile, aerobic and Gram-positive with subterminal endospores in a non-swollen sporangium. Catalase- and cytochrome $c$ oxidase-positive. Grows at $15-37{ }^{\circ} \mathrm{C}$, at $\mathrm{pH} 7-10$ and with $<8 \% \mathrm{NaCl}$ (optimum growth at about $30{ }^{\circ} \mathrm{C}$, pH 7-8 and $1-3 \% \mathrm{NaCl})$. Does not grow on MSA. Nitrate is not reduced. Citrate is not used. $\mathrm{H}_{2} \mathrm{~S}$, indole and acetoin are not produced. No fermentation or gas production from Dglucose. Gelatin, Tween 80 and casein are hydrolysed, but starch and aesculin are not. Esterase (C4), esterase lipase (C8), leucine arylamidase, valine arylamidase, $\alpha$-chymotrypsin, naphthol-AS-BI-phosphohydrolase and lecithinase are produced, but arginine dihydrolase, lysine decarboxylase, ornithine decarboxylase, urease, tryptophan deaminase, acid phosphatase, alkaline phosphatase, lipase (C14), cystine arylamidase, trypsin, $\alpha$ - and $\beta$ galactosidases, $\beta$-glucuronidase, $\alpha$ - and $\beta$-glucosidases, $N$ acetyl- $\beta$-glucosaminidase, $\alpha$-mannosidase and $\alpha$-fucosidase are not produced. Acid is not produced from any of the carbon sources in the API $50 \mathrm{CH}$ system. None of the carbon sources in the API 20E and API 20NE systems are oxidized or assimilated; also, L-alanine, L-histidine, lactic acid, L-proline, propionic acid and L-serine tested in mineral medium are not assimilated. The predominant cellular fatty acids are iso- $\mathrm{C}_{15: 0}, \mathrm{C}_{16: 1} \omega 7 \mathrm{c}$ alcohol, anteiso- $\mathrm{C}_{15: 0}$ and iso- $\mathrm{C}_{14: 0}$ and the major respiratory quinone is MK-7 (100\%). The predominant polar lipids are phosphatidylethanolamine, phosphatidylglycerol and diphosphatidylglycerol. The peptidoglycan contains mesodiaminopimelic acid.

The type strain is DS22 ${ }^{\mathrm{T}}\left(=\mathrm{DSM} 23494^{\mathrm{T}}=\mathrm{NRRL}\right.$ B $-59432^{\mathrm{T}}$ $=\mathrm{LMG} 25783^{\mathrm{T}}$ ), isolated from water of the final reservoir of a drinking-water treatment plant. The DNA G $+\mathrm{C}$ content of the type strain is $36.5 \mathrm{~mol} \%$.

\section{Acknowledgements}

The authors acknowledge the staff of the water treatment plant for help with sample collection. They thank Mrs Gabriele Pötter (DSMZ) for analysing cellular fatty acids, Mrs Bettina Sträubler (DSMZ) for performing the DNA-DNA hybridization and Mrs Ângela Alves (ICBAS) for TEM technical support. The authors also thank Professor Jianli Zhang, School of Life Science and Technology, Beijing Institute of Technology, Beijing, China, for kindly supplying $B$. oceanisediminis $\mathrm{H} 2^{\mathrm{T}}$ for comparative studies. This study was financed by the Fundação para a Ciência e a Tecnologia (project no. PTDC/AMB/70825/2006; IVM grant no. SFRH/BD/27978/2006).

\section{References}

Cashion, P., Holder-Franklin, M. A., McCully, J. \& Franklin, M. (1977). A rapid method for the base ratio determination of bacterial DNA. Anal Biochem 81, 461-466.

De Ley, J., Cattoir, H. \& Reynaerts, A. (1970). The quantitative measurement of DNA hybridization from renaturation rates. Eur $J$ Biochem 12, 133-142.

Ferreira da Silva, M., Vaz-Moreira, I., Gonzalez-Pajuelo, M., Nunes, O. C. \& Manaia, C. M. (2007). Antimicrobial resistance patterns in Enterobacteriaceae isolated from an urban wastewater treatment plant. FEMS Microbiol Ecol 60, 166-176.

Heyrman, J., Logan, N. A., Rodriguez-Díaz, M., Scheldeman, P., Lebbe, L., Swings, J., Heyndrickx, M. \& De Vos, P. (2005). Study of mural painting isolates, leading to the transfer of 'Bacillus maroccanus' and 'Bacillus carotarum' to Bacillus simplex, emended description of Bacillus simplex, re-examination of the strains previously attributed to 'Bacillus macroides' and description of Bacillus muralis sp. nov. Int $J$ Syst Evol Microbiol 55, 119-131.

Huß, V. A. R., Festl, H. \& Schleifer, K. H. (1983). Studies on the spectrophotometric determination of DNA hybridization from renaturation rates. Syst Appl Microbiol 4, 184-192.

Jukes, T. H. \& Cantor, C. R. (1969). Evolution of protein molecules. In Mammalian Protein Metabolism, vol. 3, pp. 21-132. Edited by H. N. Munro. New York: Academic Press.

Kämpfer, P., Rosselló-Mora, R., Falsen, E., Busse, H.-J. \& Tindall, B. J. (2006). Cohnella thermotolerans gen. nov., sp. nov., and classification of 'Paenibacillus hongkongensis' as Cohnella hongkongensis sp. nov. Int J Syst Evol Microbiol 56, 781-786.

Ko, K. S., Oh, W. S., Lee, M. Y., Lee, J. H., Lee, H., Peck, K. R., Lee, N. Y. \& Song, J.-H. (2006). Bacillus infantis sp. nov. and Bacillus idriensis sp. nov., isolated from a patient with neonatal sepsis. Int $J$ Syst Evol Microbiol 56, 2541-2544.

Kuykendall, L. D., Roy, M. A., O’Neill, J. J. \& Devine, T. E. (1988). Fatty acids, antibiotic resistance, and deoxyribonucleic acid homology groups of Bradyrhizobium japonicum. Int J Syst Bacteriol 38, 358-361.

Logan, N. A., Berge, O., Bishop, A. H., Busse, H.-J., De Vos, P., Fritze, D., Heyndrickx, M., Kämpfer, P., Rabinovitch, L. \& other authors (2009). Proposed minimal standards for describing new taxa of aerobic, endospore-forming bacteria. Int J Syst Evol Microbiol 59, 2114-2121.

Manaia, C. M., Nogales, B., Weiss, N. \& Nunes, O. C. (2004). Gulosibacter molinativorax gen. nov., sp. nov., a molinate-degrading bacterium, and classification of 'Brevibacterium helvolum' DSM 20419 as Pseudoclavibacter helvolus gen. nov., sp. nov. Int J Syst Evol Microbiol 54, 783-789.

Mesbah, M., Premachandran, U. \& Whitman, W. B. (1989). Precise measurement of the $\mathrm{G}+\mathrm{C}$ content of deoxyribonucleic acid by highperformance liquid chromatography. Int J Syst Bacteriol 39, 159167.

Murray, R. G. E., Doetsch, R. N. \& Robinow, F. (1994). Determinative and cytological light microscopy. In Methods for General and Molecular Bacteriology, pp. 21-41. Edited by P. Gerhardt, R. G. E. Murray, W. A. Wood \& N. R. Krieg. Washington, DC: American Society for Microbiology.

Norton, C. D. \& LeChevallier, M. W. (2000). A pilot study of bacteriological population changes through potable water treatment and distribution. Appl Environ Microbiol 66, 268-276.

Rhuland, L. E., Work, E., Denman, R. F. \& Hoare, D. S. (1955). The behaviour of the isomers of $\alpha, \varepsilon$-diaminopimelic acid on paper chromatograms. J Am Chem Soc 77, 4844-4846. 
Schleifer, K. H. \& Kandler, O. (1972). Peptidoglycan types of bacterial cell walls and their taxonomic implications. Bacteriol Rev 36, 407-477.

Smibert, R. M. \& Krieg, N. R. (1994). Phenotypic characterization. In Methods for General and Molecular Bacteriology, pp. 607-654. Edited by P. Gerhardt, R. G. E. Murray, W. A. Wood \& N. R. Krieg. Washington, DC: American Society for Microbiology.

Sneath, P. H. A. (1986). Endospore-forming Gram-positive rods and cocci. In Bergey's Manual of Systematic Bacteriology, vol. 2, pp. 11041139. Edited by J. T. Staley, M. P. Bryant, N. Pfennig \& J. G. Holt. Baltimore: Williams \&Wilkins.

Tamura, K., Dudley, J., Nei, M. \& Kumar, S. (2007). MEGA4: Molecular Evolutionary Genetics Analysis (MEGA) software version 4.0. Mol Biol Evol 24, 1596-1599.

Tiago, I., Teixeira, I., Silva, S., Chung, P., Veríssimo, A. \& Manaia, C. M. (2004). Metabolic and genetic diversity of mesophilic and thermophilic bacteria isolated from composted municipal sludge on poly-epsilon-caprolactones. Curr Microbiol 49, 407-414.

Tindall, B. J. (1989). Fully saturated menaquinones in the archaebacterium Pyrobaculum islandicum. FEMS Microbiol Lett 60, 251-254.

Vaishampayan, P., Probst, A., Krishnamurthi, S., Ghosh, S., Osman, S., McDowall, A., Ruckmani, A., Mayilraj, S. \& Venkateswaran, K. (2010).
Bacillus horneckiae sp. nov., isolated from a spacecraft-assembly clean room. Int J Syst Evol Microbiol 60, 1031-1037.

Vaz-Moreira, I., Nobre, M. F., Nunes, O. C. \& Manaia, C. M. (2007a). Gulbenkiania mobilis gen. nov., sp. nov., isolated from treated municipal wastewater. Int J Syst Evol Microbiol 57, 1108-1112.

Vaz-Moreira, I., Faria, C., Nobre, M. F., Schumann, P., Nunes, O. C. \& Manaia, C. M. (2007b). Paenibacillus humicus sp. nov., isolated from poultry litter compost. Int J Syst Evol Microbiol 57, 22672271.

Vaz-Moreira, I., Figueira, V., Lopes, A. R., Pukall, R., Spröer, C., Schumann, P., Nunes, O. C. \& Manaia, C. M. (2010). Paenibacillus residui sp. nov., isolated from urban waste compost. Int J Syst Evol Microbiol 60, 2415-2419.

Wayne, L. G., Brenner, D. J., Colwell, R. R., Grimont, P. A. D., Kandler, O., Krichevsky, M. I., Moore, L. H., Moore, W. E. C., Murray, R. G. E. \& other authors (1987). International Committee on Systematic Bacteriology. Report of the ad hoc committee on reconciliation of approaches to bacterial systematics. Int J Syst Bacteriol 37, 463-464.

Zhang, J., Wang, J., Fang, C., Song, F., Xin, Y., Qu, K. \& Ding, K. (2010). Bacillus oceanisediminis sp. nov., isolated from marine sediment. Int J Syst Evol Microbiol 60, 2924-2929. 